\title{
A COMPARATIVE ANALYSIS OF BIOETHICAL ISSUES FROM VIEW POINTS OF RELIGIOUS AFFAIRS ADMINISTRATION IN TURKEY, ROMAN CATHOLICISM AND ORTHODOX JUDAISM
}

\author{
Cemal Huseyin Guvercin ${ }^{1,2}$, Kerim M. Munir ${ }^{2}$
}

\begin{abstract}
The arguments set forth by religious authority are important since it play a crucial role in shaping the social values of the public and influence the decision of individuals in the practice pertaining to bioethical issues. The Religious Affairs Administration (RAA) was established at the inception of the Republic of Turkey in 1924 to guide religious considerations moving out of the Ottoman caliphate to a secular bioethical framework. In this article, the bioethical views of the RAA under Islamic tradition is examined and contrasted with those influenced by the Roman Catholic and Orthodox Judaic traditions. On bioethical deliberations related to the beginning and end-of-life, all three religious traditions justify sacredness of life and that of God's will in preservation it. Assisted reproduction techniques between spouses is considered to be appropriate, although third party involvement is explicitly forbidden. Organ transplantation is approved by all three religious traditions, except uterine transplantation. The contraceptive practices are approved under certain conditions - the views differ most on approaches to contraception and the appropriateness of methods. The RAA has judgement on cloning is to prohibit it, like Roman Catholicism and Orthodox Judaism. In other topics, cosmetic surgery and gender determination are approved only for treatment.
\end{abstract}

Key words: bioethics, Turkey, religious affairs administration, Roman Catholicism, Orthodox Judaism

Análisis comparativo de temas bioéticos desde el punto de vista de la Administración de Asuntos Religiosos, la iglesia católica romana y la judía ortodoxa en Turquia

Resumen: Los argumentos expuestos por autoridades religiosas son importantes ya que juegan un rol crucial en la formación de valores sociales de las personas e influyen en las decisiones individuales en la práctica en temas bioéticos. La Administración de Asuntos Religiosos (AAR) se estableció en el inicio de la República de Turquía en 1924 para guiar consideraciones religiosas desde el califato Otomano hacia una estructura bioética secular. En este artículo, se examinan los puntos de vista bioéticos de la AAR bajo la tradición islámica y se contrasta con aquellos de la tradición Católica Romana y la Judía Ortodoxa. En la deliberación bioética sobre el comienzo y el final de la vida, las tres tradiciones religiosas justifican que la vida es sagrada y que es la voluntad de Dios preservarla. Las técnicas de reproducción asistida entre esposos es considerado apropiado, aunque la participación de un tercero es explícitamente prohibido. Las tres tradiciones religiosas aprueban el trasplante de órganos, excepto el trasplante de útero. Las prácticas anticonceptivas se aprueban bajo ciertas condiciones -los puntos de vista difieren en su mayor parte en la forma de aproximarse y en la propiedad de los métodos. AAR juzga la clonación y la prohíbe, así como el Catolicismo Romano y el Judaísmo Ortodoxo. En otros temas, la cirugía cosmética y la determinación de género se aprueban solo para tratamiento.

Palabras clave: bioética, Turquía, Administración de Asuntos Religiosos, catolicismo romano, judaísmo ortodoxo

Análise comparativa de questóes bioéticas do ponto de vista da Administraçáo de Assuntos Religiosos, Igreja Católica Romana e Judaísmo Ortodoxo na Turquia

Resumo: Os argumentos estabelecidos por autoridades religiosas são importantes uma vez que eles desempenham um papel crucial na formação de valores sociais na população e influenciam a decisão dos indivíduos na prática referentes às questôes de bioéticas. A Administração de Assuntos Religiosos (AAR) foi criada na concepção da República da Turquia em 1924 para guiar consideraçóes religiosas, deslocando-se do califado otomano para uma estrutura bioética secular. Neste artigo, as perspectivas bioéticas da RAA sob tradição islâmica são examinadas e contrastadas com aquelas sob influência da Igreja Católica e de tradiçôes judaicas ortodoxas. Sobre deliberaçôes bioéticas relacionadas com o início e o fim da vida, todas as três tradiçóes religiosas justificam a sacralidade da vida e que a vontade de Deus está em sua preservação. Técnicas de reprodução assistida entre cônjuges são consideradas adequadas, embora o envolvimento de terceiros é explicitamente proibido. Transplantação de órgãos é aprovada por todas as três tradiçôes religiosas, exceto transplante uterino. As práticas contraceptivas são aprovadas sob certas condiçóes — os pontos de vista diferem em abordagens sobre a contracepção e a adequação dos métodos. A decisão da AAR a respeito da clonagem é a sua proibição, assim como no catolicismo romano e no judaísmo ortodoxo. Em outros tópicos, cirurgia plástica e a determinaçáo de gênero são aprovadas somente para tratamento.

Palavras-chave: bioética, Turquia, Administração de Assuntos Religiosos, catolicismo romano, judaísmo ortodoxo

${ }^{1}$ Dokuz Eylul University, Faculty of Medicine, Department of Medical History and Ethics Izmir, Turkey

Correspondence: cemalcin@yahoo.com

${ }^{2}$ Division of Developmental Medicine, Boston Children's Hospital, Harvard Medical School, Boston, Massachusetts, USA 


\section{Introduction}

Bioethics, is a field of study concerned with the moral, legal, political, and social issues raised by medicine, biomedical research, and life sciences technologies, as genetic engineering, stem cell research, asisted reproduction methods, organ transplants, and care of the terminally ill(1). The issues of the bioethics are generally the most controversial, and many of these issues are also important for religions. While contemporary philosophical approaches in bioethics draw upon secular presumptions, religion continues to play an important role in both personal moral reasoning and public debate(2). According to "Study on Religious Life in Turkey" (2014), 77\% of subjects in a national sample reported that they always think of pleasing God with their deeds in decisions in daily life, and $65 \%$ of subjects reported that they always manage their daily lives according to religious commands. Bioethical issues in terms of religion perspectives represent a broad array of ethical dilemmas in Turkey, as elsewhere, but may not have been elucidated in prior studies. It is important to know the different perspectives of religions on bioethical issues, because these beliefs and values may guide patients and health care professionals as they seek or provide health care(3). Therefore bioethicists should have an understanding of how religious models of morality, illness, and healing influence deliberations within the health care field(2). In this study, the viewpoints of Roman Catholicism, Orthodox Judaism and the Turkish Presidency of Religious Affairs, which represents Islam perspectives on key bioethical issues were examined. The Religious Affairs Administration (RAA) is a public service institute established under the Prime Ministry in the Republic of Turkey on 3 March, 1924, the same day the four centuries-old Ottoman caliphate was abolished(4). Caliphate is a political and legal office of administration emerging after Prophet Muhammed died in 632 A.D. (Akgun 1981).

The purpose of comparing the views of Abrahamic religions to bioethical issues is not to evaluate the accuracy, validity, or superiority of them, or to try to bring these approaches to a common point. On the contrary, all three beliefs are accepted in the same category, evaluating approaches to basic bioethics issues, the arguments they are based on, and the decision-making methods related to them, and revealing their similarities and differences.

\section{Opinions of Religious Affairs Administration}

\section{Family Planning}

The RAA considers Family Planning (FP) in a positive light in order to mitigate the risks paused by unintended pregnancies for the health of the mother, as well as the future care of the child within the family unit. The FP methods such as coitus interruptus, the use of condoms, contraceptive pills, and other hormonal methods are approached positively. Permanent methods such as tubal ligation and vasectomy are not deemed suitable unless medicaly indicated - making changes on procreation through permanent methods as being paramount to denial of abilities and blessings given by Allah and violation of a person's fundamental rights. The use of intrauterine devices (IUD) is also approached cautiously. As this method may harm and annihilate the fertilized egg, this mechanism is considered equivalent to abortion (RAA 2013).

\section{Abortion}

According to the Islamic belief, RAA considers life to start at conception, i.e., the moment of fertilization. The fetus' right to live is given by the creator (Allah), and not from the parents who do not to have the right to terminate life. The Quran and hadiths specify termination of a pregnancy, without any reasonable medical rationale, as equivalent to homicide and consider it forbidden. There is no mention related to miscarriage. There is no consensus among legal scholars as to which phase a fertilized egg is regarded as a fetus, and when it ought to be preserved. Nonetheless, some traditions do not consider the fetus as fully formed before the first 40 days. It is thought that the fetus remains lifeless and vague before this period waiting for its 'soul to be blown'. Abortion following the soul-blowing (after the 120th day according to Hanafi and 40th day according in Maliki and Hanbali traditions) is generally prohibited, and abortions before these periods are deemed mekruh, i.e., reprehensible but not necessarily forbidden. In the official RAA documents in case of an abortion, a penalty-compensation called gurre is 
paid and specified as a form of blood money in the form of approximately 212.5 grams of gold (the current value of 212.5 grams of gold about 9000 USD.) or 1785 grams of silver coins or five sacrificed camels (RAA 2013). The RAA's opinion on abortion is negative with the exception of essential medical reasons. For example, abortion is a medical must when the mother has a terminal illness and the only option is abortion for her survival or for her not to lose one of her organs such as liver and eye. RAA also allows abortion when the fetus has heavy anomalies that conflict with the nature of life and in case of rape(5).

\section{Suicide}

According to the RAA the source of the fundamental right to life belongs to the creator. This is regarded as a blessing bestowed by Allah upon an individual under certain terms and conditions. Islam does not grant people the right to commit suicide regarding this as an annihilation of their lives through their own hands, and forbids suicide and considers it as one of the major sins (RAA 2013).

\section{Fasting to Death}

The RAA considers certain behaviors leading to one's death within the scope of suicide. It is a farz (religious duty) to eat and drink adequately enough to survive; hunger strike leading to death by avoiding this duty is considered as suicide. Specifically, in case of a starvation threat that may lead to death, Islam allows even the forbidden foods (such as pork) to be eaten and therefore aims to protect and save human life. One's reluctance to make an effort to rescue individuals from such actions that could lead to their death are also regarded as suicide. Therefore, hunger strike leading to death is deemed as forbidden in any form (RAA 2013) Although RAA does not approve fasting to death, it has not delivered any view or recommendation for any intervention against the person's will to prevent or get rid of fasting to death.

\section{Euthanasia}

According to the RAA euthanasia is regarded as absolutely inconsistent with Islamic proactrice; a person cannot decide when to die as this is the determination of the creator. Moreover, any person who ends their life through euthanasia commits a sin, and others who approve such acts including medical professionals who may not administer the requisite treatment to assit in survival are also sinning and morally responsible for the outcome. According to the Quran's teachings men are created to worship God who is the owner of life and they cannot rid a life given by God. Furthermore, they ought to show gratitude and ask for healing from God when grappling with death (RAA 2013).

\section{Withdrawal of Life Support}

According to the RAA documents, it is forbidden in Islam for a person to end life even though there is no medical hope to survive, and furthermore, there is accompanying severe pain. A person connected to life support may be disconnected provided that it is officially decided with certainty by a quorum of physicians that the brain has lost all its functions and it will be impossible to recover (brain death) (RAA 2013). According to the RAA Higher Council, the five principles called Maqasid al Shariah,i.e., religion, life, mind, generation, and property ought to be protected. According to the principle of protecting property, it has been concluded that if life is unrecoverable and its support is to be maintained at a high cost, it may be appropriate to withdraw support from such a patient; indeed this may be regarded as necessary to prevent depletion of needed resources by others in society (RAA 2009). In this context, passive euthanasia is not totally rejected under specified circumstances.

\section{Brain Death}

Brain death is defined as complete loss of brain activities such as irreversible coma, absence of brain stem reflexes, and respiration over a sustained 24 hour period(6). After brain death is medically established, however, if an individual is a donor, care and protection support is maintained until the organs are transplanted to recipients. The RAA accepts the medical criteria for brain death. However, since heartbeat and respiration continue when connected to life support devices, two different views are important relating to decisions regarding brain death. According to the first view, supported by the International Islamic Law Council, medically determined brain death coincides with 
the real religious death. According to the second (and majority) view, real death can only occur after the soul leaves the body and may not necessarily coincide with the medically determined brain death (RAA 2009). Therefore, this may delay the validity of post-mortem dispositions (including inheritance) and organ donation.

\section{Organ Transplantation}

Organ transplantation is considered by the RAA within a broad framework that considers that "the necessity makes the forbidden permissible." The conditions for approval of transplantaion practices include: i) medical necessity; ii) certainty of donor's death; iii) absence of any fiduciary transaction between donor and recipient; iv) donor family consent; and v) recipient patient consent (RAA 2013). The RAA generally approaches the issue of organ transplantation positively with the exception of uterine transplants consistent with the view on IVF practice only within married couples (see below).

\section{Assisted reproductive techniques}

According to the RAA, out of wedlock childbirth are prohibited, as it may alter social cohesion. The RAA adopts the opinion that within the scope of religious principle a legitimate child belongs only to a married husband and wife. It is permissible to perform in-vitro fertilization (IVF) and place it in the uterus of the mother-to-be only if the couple is married. When third party donor or surrogate is involved this is viewed under adultery and considered as sinful and forbidden. Conceiving a child with another man's sperm and establishing sperm banks are also not accepted. The RAA considers a parsimony in IVF methodology, especially if more than one blastocyst (fertilized egg) is produced. The destruction of blastocysts, their use in research or treatment is regarded as an inconvenience; iadvises that whenever possible no more than needed ovum should be fertilized in IVF practice, otherwise it will be tantamount to prescribing abortion (RAA 2013).

\section{Sperm/Ovum Cryopreservation and Donation}

The issue of cryopreservation and donation of ovum and sperm is restricted to married couples. Transferring sperm/ovum to others outside the marriage is not permitted (RAA 2013).

\section{Gender Predetermination}

The RAA states that the predetermination of an unborn child's gender may cause a number of demographical and ecological problems and disrupt the balance of gender distribution in particular in favor of male infants. Quran considers a child's gender to be determined by Allah, and gender selection is not appropriate in religious terms as long as there is no medical/genetic indication (RAA 2013).

\section{Therapeutic stem cell research}

Stem cells, which have the characteristics of unlimited division and differentiation for the desired tissue, are obtained from embryos, fetal tissues, and adult tissues. In this regard, the main ethical problems depend on the concerns related to research methods and potential results, e.g., destruction of human embryos and may lead to even inhumane practice $(7,8)$. The RAA opinion deems appropriate to conduct stem cell research based on adult cells, but not on embyos or fetal tissues, since embryonic stem cells have the potential of being a person and ought not be used like spare parts. The therapeutic use of specialized adult stem cells which do not have the potential of being an independent living being is considered as equivalent to organ transplantation. In vital exceptional cases, the use of blastocysts, left from IVF for therapeutic purpose is accepted (RAA 2013).

\section{Cloning}

According to RAA, with the statements "Verily, all things have We created in proportion and measure." and "And the heaven He has raised high, and He has set up the Balance. In order that you may not transgress (due) balance.", Quran says that there is a unique order and delicate balance in the universe and responsibility to protect it is granted to human being. RAA strictly bans human cloning studies on the grounds that it is not consistent with the purpose of creation of human being, has a potential to disrupt natural balance 
and harm human honor, and can violate personal rights and bring harm to family structure, relationships by affinity, and social order. However, cloning is allowed on animals, plants, and microorganisms provided that animals are not tortured and ecological balance is not disrupted(9).

\section{Cosmetic Surgery}

The RAA approves esthetic interventions to be performed for treatment purposes. The performance ought not signify a change in the innate characteristics of a person and change (damage) God's intended creation. Cosmetic surgery is therefore condoned only if it provides a medically indicated advantage and does not alter a person's innate characteristics. Any cosmetic surgery that deceive others is regarded as non-permissible; this includes gender reassigment procedures and other operations that may lead to legal identity confusion and misunderstanding (RAA 2013). RAA does not allow female circumcision, which is traditionally and commonly performed in some Islamic countries(10).

\section{Opinions of Orthodox Judaism}

Judaism is the religion and way of life of the Jewish people. The Orthodox Judaism is the only movement formally and legally recognized by State of Israel(11). This is why only Orthodox Judaism has been focused on. In Judaism, it is mankind's obligation to reproduce and ensure that new generations are raised. When God created man and woman, His first command in the Old Testament was, "Be fruitful and multiply. Fill the Earth and subdue it." Reproduction is not regarded as an arbitrary process; it is also considered an obligation for the family. In this context, birth control is opposed. Limiting the number of children by reducing births is considered to be against the "reproduction" commandment, and wasting one's reproduction possibilities is considered to be one of the major sins (Yasdiman 2001). Classical sources of Jewish law about abortion implies that: (1) The only indication considered for abortion is a hazard to the mother's life. (2) Otherwise, the destruction of an unborn child is a grave offence, although not murder. (3) It can be viewed that the fetus is granted some recognition of human life, but it does not equal that of the mother's and can be sacrificed if her life is in danger(11). Reformist tradition within Judaism approach contraception more positively, compared to Orthodox tradition and is beyond the intended scope of this paper. There are two main principles on this matter: The first one is that it is commanded to wed and have a child. The other one is that methods where sperm is to be harmed are prohibited. In this regard, the use of the contraceptive pill and intrauterine device are acceptable; whereas, the use of condoms and diaphragms is not deemed appropriate.

The 6th of the Ten Commandments is "thou shalt not kill". Additionally, in the Genesis chapter of Torah, the sanctity of human life and that God created man in his own image is emphasized $(12,13)$. Life and consciousness are gifts of God, and as a Lord of life. God alone should determine when and how humans die(14). Further, it is not rightful to kill a person with any disability, incurable disease, or a person in a persistent vegetative state. This is because life does not belong to man, it is owner by God who bestowed it upon humankind and no one else. Every moment of life is intrinsically precious and quality of life is not paramount. According to Jewish law, therefore, it is forbidden to withdraw life support and condone actively ending a consenting terminally ill patients' life. Some Rabbis encourage praying for the naturally dying terminally ill person whose pain cannot be relieved. They are not in favor of the practice to prolong life. They specify that treatments to interrupt natural death ought to be avoided for terminally ill patients. This situation has inevitably been interpreted as an indirect approval of passive euthanasia. Nevertheless, Jewish law is against the withdrawal of life support(15).

Judaism also prohibits suicide, hunger strike leading to death, euthanasia, witholding of treatment or withdrawal of life support and abortion, based on the core principle of "sanctity of life". Exception of the abortion prohibition include the danger to the life and health of the pregnant mother(16). The development of the embryo and fetus into a human being is considered as a progressive process. There are significant differences particularly between pre-implanted and implanted embryos. It is traditionally held that it takes almost 40 days for a fertilized egg to be implanted in the uterus. Therefore, some authorities have a more 
positive attitude towards abortions within this period and consider it not forbidden(17). However, the dominant opinion is that abortion is equivalent to homicide and it should be completely forbidden(18).

The Torah tells humankind to reproduce in all ways natural and artificial. In line with this reproduction principle, pregnancy is approached positively though assisted reproductive techniques such as IVF and embryo transfer. As in the Islam, the sperm and egg must belong to the wedded couple. Destruction of extraneous embryos produced through IVF technique, using them in research or donating them to another infertile couple are all prohibited(19-21). The practice of sperm donation is not considered as adultery as there is no sexual intercourse; however this practice is not approached favorably. The biological father of a child born through sperm donation is considered to be the donor rather than the infertile male. In case of egg donation, two motherhood types are recognized: genetic (owner of the egg) and gestational (host of pregnancy and birth). Since Judaism comes form the mother, an infant conceived through egg donation is consider Jewish only if a genetic mother is Jewish(19). Some authorities claim that egg donor woman should not be married in order to avoid adultery(21).

In Judaism all life is infinitely precious and holy and every moment of life should be protected. From this point of view, precisely defining and determining the moment of death is a delicate subject. Especially after life support units have increasingly been involved in medical care, the concept of brain death has become a topical issue, as such persons are the source of organ donations. The identification of the absolute moment of death has led to considerable discussion. According to Orthodox Judaism, brain death criteria: (i) knowledge of the cause of illness; (ii) absolute absence of spontaneous respiration; (iii) clinical display of brain stem destruction; (iv) support for clinical diagnosis of death with absence of brain stem reflexes; and (v) absence of respiration and brain stem activity for a period of at least 12 hours despite the treatment $(22,23)$.

Judaism also approaches the subject of organ transplantation positively. However, some Ortho- dox denomination supports organ transplantation performed among only Jewish persons(24). Judaism overall allows organ transplantation from cadaver in case that the following conditions are met: (i) recipient in need of an organ; (ii) recipient's life is in danger; (iii) consent expressed by the donor while healthy. Artificial organ or organpart transplants, such as cardiac valves, as well as prostheses, such as hip or knee arthroplasty, are all approached positively, without objection to organ and tissue transplantation from non-human animals(25).

Cosmetic surgeries that do not serve a legitimate medical purpose are not favored. Interventions performed for purposes such as correcting physical deformities or ensuring functional development are not deemed appropriate if conducted solely for cosmetic purposes(26). Therefore, cosmetic surgeries are not allowed to solve psychological problems or for beautification(27). If the practice to be conducted cannot be sufficiently justified in this respect, it can be evaluated in the "self-harm" category which is forbidden(26).

Judaism has a permissive approach concerning stem cell research. It allows approves the use of embryonic stem cells in therapeutic stem cell research, but it is prohibited to use embryos after 40 days. The focus is on the protection of life, the moral status of the embryonic tissue is secondary. All religious rules may be violated in order to preserve/save even a single life. The exception of this rule is specified as adultery, homicide, and idolatry. Therapeutic stem cell research is regarded favorably as having a potential for cure of disease and preservation of life(28).

Even though there is generally a negative stance towards cloning an overall consensus has not been reached as religious identity comes from the mother but lineage comes from the father and is transferred from generation to generation. Since parthenogenesis (asexual reproduction) replaces sexual reproduction in reproductive cloning, the problem of who are the parents are significant questions(29). The Union of Orthodox Jewish Congregations of America and the Rabbinical Council of America stayed that "if cloning tech- 
nology research advances our ability to heal humans with greater success, it ought to be pursued since it does not require or encourage the destruction of life in the process"(30). Reproductive cloning, however, is opposed, and therefore careful oversight of research must be in place(31). Although having a son is important in Judaism, generally gender predetermination is not allowed(32). However, pre-implantation gender determination is only permitted for viability in certain genetic disorder(17).

\section{Opinions of Roman Catholics}

More than half of the Christians are Roman Catholics and hence the contrast with this group in this paper(33). The Roman Catholic Church (RCC) finds out of wedlock sexual relations to be morally wrong; natural birth control methods are to be used only by married couples for the purpose of adjusting the size of the family and frequency of birhts. The use of medical contracetpion methods are forbidded(34).

The RCC acknowledges that life starts with fertilization and therefore an inductio of abortion is a great sin. The soul enters the body at the moment of conception; from that moment on, the fetus is therefore a person and abortion performed in any stage would be a reason for denunciation. Several authors have pointed to the time of implantation, at about fourteen days, as a "line" after which individuality appears more settled (the possibility of "twinning" being past) and the chance of survival greatly magnified $(34,35)$.

According to RCC, any killing of an innocent person directly and intentionally to be a great sin and an immoral act, this unequivocally stating that such practices as abortion, euthanasia, and destruction of human embryos in medical research are not approved. Abortion can be vital if there is danger to the life of the pregnant woman or the presence of severe anomalies on the fetus that would not allow viable adaptation to life(36).

The RCC forbids egg donation for either altruistic purposes or in return for payment. Reproduction and sexual intercourse are inseparable and one always should accompany the other. The Church forbids the use of IVF even within marriage. The destruction of extra embryos through IVF is a significant problem(21). IVF is permitted under circumstances where extra embryos would not be produced (and destroyed), eggs and sperm of married couple would be used, and it would not replace sexuality in marriage (RSR 2014). RCC also refuses genetic diagnosis for gender pre-determination for non-therapeutic purposesand considers it against human dignity and integrity(37).

According to Roman Catholic tradition, acquiring sperms through masturbation for sperm donation is considered as a violation of the 6th Commandment (thou shall not kill). Additionally, it raises moral questions as to who will be the real parents in ensuing surrogate pregnancies, parental rights, child's right to know their parents, and the risk of hereditary diseases. All these influence the church's negative opinion on this practice since it is considered against the will of God and plays the role of $\operatorname{God}(38)$.

All different Christian denominations hold positive views on organ transplantation from both living persons and cadavers. They do not approve donations from anencephalic children whose parents consent or donations following active euthanasia. RCC stated that organ trade is against the human dignity and is a morally inacceptable act, and no discriminatory criteria are approved in organ transplantation $(24,39)$.

Since man was created in God's image, Roman Catholic doctrine is against euthanasia since it considers life a gift from God. The decisions related to life ought to be respected even if costly. According to Evangelium Vitae, killing of anyone cannot be accepted even if a person's condition is incurable and euthanasia is regarded as a great violation of God's law, similarly attempting to commit suicide or assisting in suicide is morally wrong. On the other hand, refusal of intensive treatments to extend life are morally acceptable and consodered as different than euthanasia. The RCC allows discontinuation of life support for terminally ill patients where the expected benefit is very low(40). The Vatican Declaration on Euthanasia states that it permits treatments used to relieve the pain of terminally ill patients even if they have life-shortening unwanted side effects (double effects) (41). Whereas palliative treatment 
is recommended, active euthanasia is absolutely not permitted $(40)$.

According to RCC, death is required to be defined based on neurological criteria. These neurological criteria consist of 4 findings: (i) coma or full nonresponse condition; (ii) absence of motor responses to painful stimuli in all organs; (iii) absence of brain stem reflexes; and (iv) absence of spontaneous respiration. Pope stated that the church does not have the competence to define death, and this definition can only be made by medicine suitably. Death takes place when the soul eternally leaves the body (NCBC 2015).

The focus regarding question of stem cell research is the source from which the cells are derived. It permits research on stem cells obtained from adult cells or from umbilical cords. However, it forbids obtaining stem cells from embryonic sources. It also forbids cloning for reproductive purposes as being against the will of God. Whenever cloning is in question, an individual plays the role of God and the concept of parenthood is entirely transformed. The Catholic tradition focuses on the significance of family for the well-being of society. It has opinions that reproduction of a person through cloning disregards the sanctity of life, shakes the family structure to its foundations, harms the unity of marriage, and disturbs the balance of nature $(42,43)$.

Although the RCC was against cosmetic surgery in the past, today this opinion has been partly altered. In pursuance of the integrity principle of the human body, authorities now approve cosmetic surgery and argue that a deformed part may be sacrificed to benefit its integrity. Cosmetic surgeries should not merely be conducted for beautification and fashion purposes, and should not risk one's general health. Even though they do not aapprove that cosmetic surgery be performed to alleviate mental problems, one may argue that mental ill-health is also part of one's spiritial integrity. Nonetheless, this issue is not yet included under the exemtpions for approving cosmetic surgery to alleviate suffering. According to some Christian authorities, cosmetic surgery is not against the will of God and they may restore mankind's defective creation $(27,44)$. However, RCC has recently expressed quite a negative view on plastic surgery among women: "Plastic surgery is a form of 'aggression' against the female body like a burqa made of the flesh," (45).

The bioethical views of the three contrasting Abrahamic religions are summarized in Table 1

\section{Discussion}

Islam, Judaism, and Christianity as the world's monotheistic religions have a deep-rooted and common history, currently representing 55.2\% of the world population (GRL Report 2010). The viewpoints of these three monotheistic religions on bioethical issues on the beginning (e.g., abortion, use of IVF), end (e.g., withdrawal of life support, euthanasia), and meaning (i.e., that it represents a gift or bestowal by God) of life are remarkably similar. The viewpoints of all three religions on the issues related to the beginning of life underscore a sacredness of life that must be carefully preserved.

The RAA approaches abortion, euthanasia, suicide, hunger strike leading to death, and withdrawal of life support within the framework of sacredness and privacy of life, as in the RCC and Orthodox Judaism. RAA takes the stage called soul blowing as a turning point for abortion but, there is no common agreement on the threshold for soul blowing even among different sects of Islam. Such different approaches concerning the start of life are about not only the verses, hadiths, or religious texts to be focused on when delivering a judgment but also the society's value systems and the methods used by religious functionaries (i.e. men of God) delivering the judgments. For example, within the classical Islamic fiqh, judgments are delivered through methods called casuistry or case-based reasoning rather than normative methods. This classical method of fatwa involves some advantages and disadvantages for the solution of bioethical issues. The strong bond of this method with practical life allows making quick and effective recommendations to people who have these kinds of issues. Its weakness, on the other hand, is that it cannot generate quick, clear, and homogenous solutions when it faces individual objects not seen throughout the Islamic history (e.g. human cloning). In the view it published in 2003, RAA said that no definite judgment could be passed on cloning (RAA 2003). However, it has recently ex- 
Table-1: RAA, Roman Catholic Church and Orthodox Judaism Comparative Bioethical Views

\begin{tabular}{|c|c|c|c|c|c|c|}
\hline & \multicolumn{2}{|l|}{ RAA } & \multicolumn{2}{|c|}{ Roman Catholic Church } & \multicolumn{2}{|l|}{ Orthodox Judaism } \\
\hline & Decision & Exception & Decision & Exception & Decision & Exception \\
\hline Family Planning & Approved & $\begin{array}{l}\text { Permanent } \\
\text { Methods } \\
\text { (vasectomy, } \\
\text { tubal ligation) }\end{array}$ & $\begin{array}{l}\text { Limited } \\
\text { approval: natural } \\
\text { methods }\end{array}$ & $\begin{array}{l}\text { Modern } \\
\text { methods } \\
\text { (IUD) }\end{array}$ & $\begin{array}{l}\text { Limited } \\
\text { approval: Only } \\
\text { methods used by } \\
\text { woman approved } \\
\text { (Pills, IUD) }\end{array}$ & $\begin{array}{l}\text { Barrier methods } \\
\text { (Condom, } \\
\text { Diaphragm) }\end{array}$ \\
\hline Abortion & Forbidden & $\begin{array}{l}\text { Medical } \\
\text { Obligation }\end{array}$ & Forbidden & $\begin{array}{l}\text { Vital danger } \\
\text { to mother or } \\
\text { severe fetal } \\
\text { anomalies }\end{array}$ & Forbidden & Danger to mother \\
\hline Suicide & Forbidden & None & Forbidden & None & Forbidden & None \\
\hline Death Fast & Forbidden & None & Forbidden & None & Forbidden & None \\
\hline Active Euthanasia & Forbidden & None & Forbidden & None & Forbidden & None \\
\hline $\begin{array}{l}\text { Withdrawing of } \\
\text { Life Support }\end{array}$ & Forbidden & Brain death & Forbidden & $\begin{array}{l}\text { Futile } \\
\text { treatment }\end{array}$ & Forbidden & $\begin{array}{l}\text { Not to disrupt } \\
\text { natural death }\end{array}$ \\
\hline $\begin{array}{l}\text { Organ } \\
\text { Transplantation }\end{array}$ & Approved & Uterine & Approved & $\begin{array}{l}\text { Anencephalic } \\
\text { donors, } \\
\text { transplantation } \\
\text { after active } \\
\text { euthanasia }\end{array}$ & Approved & None \\
\hline $\begin{array}{l}\text { Assisted } \\
\text { Reproductive } \\
\text { Techniques (IVF) }\end{array}$ & $\begin{array}{l}\text { Limited } \\
\text { approval: } \\
\text { marriage }\end{array}$ & None & $\begin{array}{l}\text { Limited } \\
\text { approval: } \\
\text { Marriage, no } \\
\text { extra embryos }\end{array}$ & None & $\begin{array}{l}\text { Limited } \\
\text { approval: } \\
\text { marriage }\end{array}$ & None \\
\hline $\begin{array}{l}\text { Ovum-Sperm } \\
\text { Cryopreservation } \\
\text { and Donation }\end{array}$ & Forbidden & None & Forbidden & None & Forbidden & None \\
\hline $\begin{array}{l}\text { Gender } \\
\text { Pre-determination }\end{array}$ & Forbidden & $\begin{array}{l}\text { Medical } \\
\text { obligation }\end{array}$ & Forbidden & $\begin{array}{l}\text { Medical } \\
\text { obligation }\end{array}$ & Forbidden & $\begin{array}{l}\text { Medical } \\
\text { obligation }\end{array}$ \\
\hline $\begin{array}{l}\text { Therapeutic Stem } \\
\text { Cell Research }\end{array}$ & $\begin{array}{l}\text { Limited } \\
\text { approval: Adult } \\
\text { cells }\end{array}$ & $\begin{array}{l}\text { Embryonic stem } \\
\text { cells (unless no } \\
\text { other method) }\end{array}$ & $\begin{array}{l}\text { Limited } \\
\text { approval: Adult } \\
\text { cells/umbilical } \\
\text { Cord }\end{array}$ & None & Approved & $\begin{array}{l}\text { Stem cells from } \\
\text { embryos older } \\
\text { than } 40 \text { days }\end{array}$ \\
\hline Human Cloning & Forbidden & None & Forbidden & None & Opposed & None \\
\hline $\begin{array}{l}\text { Cosmetic } \\
\text { Surgeries }\end{array}$ & Forbidden & $\begin{array}{l}\text { Medical } \\
\text { treatment }\end{array}$ & $\begin{array}{l}\text { The negative } \\
\text { attitude }\end{array}$ & $\begin{array}{l}\text { Medical } \\
\text { treatment }\end{array}$ & $\begin{array}{l}\text { The negative } \\
\text { attitude }\end{array}$ & Medical treatment \\
\hline
\end{tabular}


pressed its view banning human cloning. Accordingly, it can be said that a lot of judgments come out on modern issues to which there are not similar cases dealt with in the Islamic history. If there is no legal regulation about a specific issue in a country, this may provide the person with a lot of possibilities in the decisions he is to make, or drag him to dilemmas and make him more involved in the issue. The Turkish law permits voluntary abortions until the 10th week of pregnancy (law no. 2827). In Turkey, legal and religious references about abortion are different.

All the three faiths forbid abortion that is not justufied on sufficient medical grounds. The Turkish Penal Code (a. 81) is also consistent with the RAA's position on euthanasia, those who aide or perform it are considered to have committed intentional homicide (Code. 2004). Euthanasia is also forbidden in the Regulation of Patient Rights (a. 13) (RPR 1998).

The RAA stance on the issue of wihdrawal of life support is of interest in that it emphasizes the question of material costs rather than patient autonomy or relatives' decision regarding withdrawal of treatment. This is a surprising utilitarian position regarding the distribution of limited resources in medicine. Nevertheless, there are different approaches in other Islamic countries regarding this question. For example, withdrawing life support from Yasser Arafat, former President of Palestinian Authority in 2004 after brain death was established was objected to by the Mufti of Jerusalem who declared that it was absolutely not appropriate to do so(46).

Opinions on brain death are very similar to the opinions of all three beliefs. They accept medical death based on medical references in terms of brain death criteria. However, real death is defined as the moment when the soul leaves the body. All three faiths allow organ transplantation from living persons and cadavers, with the exception of uterine transplantation.

Family planning is the issue on which all three faiths have the greatest variance. The RAA perspective is the most liberal allowing all methods including tubal ligation and vasectomy unless medically contraindicated, use of condoms as well as the practice of coitus interruptus. Both the Roman Catholic doctrine and Orthodox Judaism do not permit use of condoms or coitus interruptus. The RCC does not permit any modern method with the exception of natural methods pertaining to timing of intercourse and abstention. Orthodox Judaism allows all female contraceptive methods. Of course, the situation in practice is different among the practicing population in all these highly developed countries (WHO 2015).

When it comes to the use of assisted reproductive techniques, procedures involving sperm, ovum and uterine implantation are widely allowed within marriage. However, any destruction of embryos to be produced during the performance of these techniques is considered tantamount to abortion and regarded as objectionable. Attitudes and concerns of RCC and Orthodox Judaism on these issues are therefore in accord with those of the RAA.

RAA bans plastic surgery that is not for treatment purposes. Likewise, Orthodox Judaism and Roman Catholic teaching do not approach cosmetic surgeries positively, except for treatment purposes. On the question of cosmetic surgery, the issue of aesthetics is conceptually debated and criteria are often subjective, it is therefore not always easy to discern what is treatment and what is not. Particularly gender reassignment operations are not deemed as appropriate.

All three faiths similarly focus on the source of stem cell used in research. The RAA and the RCC absolutely object to the production of stem cells from embryos equating it to abortion. Orthodox Judaism has a more moderate opinion on this issue emphasizing the sanctity of saving human life. On the use of stem cells for cloning purposes RAA, RCC and Orthodox Judaism have issues unfavorable viewpoints.

\section{Conclusion}

This paper has explored the views of RAA, as a Islamic perspective, Roman Catholicism and Orthodox Judaism about key bioethical issues and compared them with each other. The purpose of comparing the approaches of different beliefs to bioethical issues is not to competation of different views. To the contrary, it may contribute to en- 
suring that each belief enriches its own approach with a critical perspective by making use of different views and adopts respecting and tolerating differences as a mentality. As every belief has different historical, cultural, and sociological backgrounds, they have different approaches and arguments regarding bioethical issues.

\section{Acknowledgements}

The section on the opinions of the Religious Affairs Administration was read at the 3rd International Islam and Bioethics Symposium, 14 -16 April 2010, Antalya, Turkey. The present work was supported, in part, by the Fogarty International Center, National Institutes of Health sponsored International Bioethics Research Education grant (5R25TW009248) at the Boston Children's Hospital, Harvard Medical School.

There is no conflict of interest in this study. 


\section{References}

1. Viens AM, Singer PA. Introduction. The Cambridge Textbook of Bioethics. Cambridge: Cambridge University Press; 2008.

2. Turner L. Bioethics and religions: religious traditions and understandings of morality, health, and illness. Health Care Anal 2003; 11(3): 181-197.

3. Bishop LJ, Coutts MC. Scope Note on Religious Perspectives on Bioethics, Part 2. Kennedy Inst Ethics J 1994 Dec; 4(4): 357-386.

4. Guvercin CH. The Viewpoints of the Presidency of ReligiousAffairs of Republic of Turkey on Various Bioethical Problems. In Arda B, Rispler V, (eds). Islam and Bioethics. Ankara: Ankara Universitesi Press; 2012: 226-234.

5. Tufekci I. Íslam Hukukuna Göre Gebeliğin Sonlandırılması (in English: According to Islamic Law Termination of Pregnancy) Marmara Üniversitesi İlâhiyat Fakültesi Dergisi, Cilt-Sayı 45, Eylül 2013: 111-154.

6. Sabanci PA, Karasu A, Karadereler S, Barlas O. Brain Death Diagnosis Journal of Neural System Surgery 2008; 1(2): 81-85.

7. Green RM. Research With Fetuses, Embryos, and Stem Cells. In Ezekiel JE, (ed.). The Oxford Textbook of Clinical Research Ethics. New York: Oxford UniversityPress; 2008: 495-497.

8. Baune Ø, Borge OJ, Funderud S, Føllesdal D, Heiene G, Østnor L. The Moral Status of Human Embryoswith Special Regard to Stem Cell Research and 17 Therapy. In Østnor L, (ed.). Stem Cells, Human Embryos and Ethics Interdisciplinary Perspectives. Oslo: Springer; 2008: 1-18.

9. Pacaci I. Klonlama ve Kök Hücre Çalışmalarının İslâm Dini Açısından Değerlendirilmesi. (in English: In Point of Islam, Evaluation of Studies Stem Cell and Cloning) Usûl 2007; 7(1): 35-60.

10. Soyer S. Kadın Sünneti: Kültürel Dayanakları ve Yol Açtığı Sorunlar. (Female Circumcision: Cultural References and Concerns it Raises). EKEV Akademi Dergisi 2014, Sayı 60: 403-414.

11. Schenker JG. Human reproduction: Jewishperspectives. Gynecol Endocrinol 2013; 29(11): 945-948.

12. Akbas M. Biyoetik Bir Sorun Olarak Ötanazi: Tarihi, Çeşitleri ve Felsefesi (in English: Euthanasia as a Bioethical Problem: History, Variety and Philosophy). Felsefe Dünyası 2010; 1(51): 6-7.

13. Inceoglu S. Ölme Hakkı. Istanbul: Ayrıntı Press; 2010: 36.

14. Banks JT. Life-Sustaining Treatment And Euthanasia. HistoricalAspects, Hebraic and Jewish Perspectives. In Encyclopedia of Bioethics. 3rd. ed. Post SG, (ed.). Vol 3. USA: Galle Cengage Learning; 2004: 1422.

15. Vanderpool HY. Hebraicand Jewish Perspectives. In Encyclopedia of Bioethics. 3rd. ed. Post SG, (ed.). Vol 3. USA: Galle Cengage Learning; 2004: 1410-1432.

16. Goldsand, G. Zahava RS, et al. Bioethics for clinicians: 22. Jewish bioethics. CMAJ 2001; 164(2): 219-222.

17. Blazer S, Etan ZZ. The Embryo: Scientific Discovery and Medical Ethics. Basel: Karger AG; 2005: 33-35.

18. Novak, D. (2004). Judaism. Bioethics. In. Encyclopedia of Bioethics. 3rd. ed. Post SG, (ed.). Vol 3. USA: Galle Cengage Learning; 2004: 1352-1353.

19. Wahrman MZ. Jewish Medical Ethics. Assisted Reproduction and Judaism 2014. Available at: http://www.jewishvirtuallibrary.org/jsource/Judaism/ivf.html (accessed: October 10, 2014)

20. Schenker JG. Ethics, legal, social counselling. Assisted reproductive practice: religious perspectives. Reproductive Biomedicine Online 2005; 10(3): 310-319.

21. Gruenbaum BF, Pinchover ZS, Lunenfeld E, Jotkowitz A. Ovumdonation: Examining the New Israeli Law. European Journal of Obstetrics \& Gynecology and Reproductive Biology 2011; 159(1): 40-42.

22. Rappaport HZ, Rappaport IT. Principles and concepts of brain death and organ donation: the Jewish perspective. Child's Nerv Syst 1998; 14: 381-383.

23. Steinberg A. Organ Transplantation and Definition of the Moment of Death - Jewish Perspectives. Available at: http://98.131.138.124/articles/Misc/transplantation.pdf (accessed: October 2, 2016)

24. Bruzzone P. Religious Aspects of Organ Transplantation. Transplantation Proceedings 2008; 40(4): 1064-1067.

25. Steinberg A. Jewish Aspects Concerning Live and Cadaver Organ Donation. Available at: http://98.131.138.124/articles/ Misc/transplantation.pdf (accessed: October 2, 2016)

26. Washofsky RM. Jewish Living: A Guide to Contemporary Reform Practice. USA: UAHC Press (Union of American Hebrew Congregations): 21 .

27. Gilman SL. Creating Beauty to Cure the Soul. Raceand Psychology in theshaping of Aesthetic Surgery USA, Duke UniversityPress; 1998: 132-136.

28. Jafari M, Elahi F, Ozyurt S, Wrigley T. Religious Perspectives on Embryonic Stem Cell Research. In Renwick Monroe 
K, Miller R RB, Tobis JS, (eds.). Fundamentals of the Stem Cell Debate: The Scientific, Religious, Ethical, and Political Issues. London, University of California Press; 2008: 84-86.

29. Eisenberg D. Issues in Jewish Ethics. The Ethics of Cloning. 1997. Avaliable at: http://www.jewishvirtuallibrary.org/jsource/Judaism/clone.html (accessed: January 15, 2015).

30. Frazzetto G. Embryos, cells and God. EMBO Rep 2004; 5(6): 553-555.

31. Cole-Turner, R. Embriyo and Fetus. Religious Perspectives. In: Encyclopedia of Bioethics. 3rd. ed. Post SG, (ed.). Vol 3. USA: Galle Cengage Learning; 2004: 732-739.

32. The Jewish Week. Rabbis At Fertility Conference OK Gender Selection. Avaliable at: http://www.thejewishweek.com/ news/breaking-news/rabbis-fertility-conference-ok-gender-selection (accessed: October 2, 2016).

33. Schenker JG. Women's reproductive health: monotheistic religious perspectives. International Journal of Gynecology \& Obstetrics 2000; 70; 77-86.

34. Cahill LS. Abortion. Religious Traditions. In: Encyclopedia of Bioethics. 3rd. ed. Post SG, (ed.). Vol 3. USA: Galle Cengage Learning; 2004: 31-35.

35. Vatican. Catechism of the Catholic Church. Available at http://www.vatican.va/archive/ccc_css/archive/catechism/ p3s2c2a5.htm (accessed: August 2, 2016).

36. Vatican. Evangelium Vitae. Available at http://w2.vatican.va/content/john-paul-ii/en/encyclicals/documents/hf_jp-ii_ enc_25031995_evangelium-vitae.html (accessed: August 2, 2016).

37. Amundsen DW. The Discourses of Roman Catholic Medical Etics. In: ed. Baker BR, Mc Cullough AJ, (eds.). The Cambridge World History of Medical Ethics. Cambridge: Cambridge University Press; 2009: 218-254.

38. Fleischmann R. A Biblical Look at Sperm Donation. 1984. Available at: http://www.christianliferesources.com/article/abiblical-look-at-sperm-donation-748 (accessed: October 17, 2014).

39. Vatican. Address of The Holy Father John Paul II to the 18th International Congress of The Transplantation Society. Available at http://w2.vatican.va/content/john-paul-ii/en/speeches/2000/jul-sep/documents/hf_jp-ii_spe_20000829_ transplants.html (accessed: August 21, 2016).

40. Bülow HH, et al. The World's Major Religions' Points of Wiev on end-of-life Decisions in the Intensive Care Unit. Intensive Care Med 2008; 34(3): 423-430.

41. Sacred Congregation for the Doctrine of the Faith. Declaration on Euthanasia. 1980. Avaliable at: http://www.vatican. va/roman_curia/congregations/cfaith/documents/rc_con_cfaith_doc_19800505_euthanasia_en.html (accessed: October 2, 2016)

42. Jackson W. The Ethics of Human Cloning. Avaliable at: https://www.christiancourier.com/articles/353-ethics-of-humancloning-the (accessed: September 21, 2014)

43. Lauritzen P, Nathaniel S. Cloning. In: Encyclopedia of Bioethics. 3rd. ed. Post SG, (ed.). Vol 1. USA: Galle Cengage Learning; 2004: 462-466.

44. Padela AI. Medical Ethics in Religious Traditions: A Study of Judaism, Catholicism, and Islam. JIMA 2006; 38: 106117.

45. Vatican. Women's Cultures: Equality and difference. Available at http://www.cultura.va/content/dam/cultura/docs/pdf/ Traccia_en.pdf (accessed: July 7, 2016).

46. Gazetesi V. Kudüs baş müftüsü açıklamalarda bulundu (in English: Grand Mufti of Jerusalem speech on). (November 10, 2004).

Received: January 11, 2017

Accepted: June 24, 2017 